\title{
Umbilical Cord Hernia Associated with a Patent Urachus: A Case Report
}

María SC ${ }^{1^{*}}$, Pedro-José LE², Marina $\mathrm{PS}^{3}$, Carolina $\mathrm{AM}^{4}$

\author{
${ }^{1}$ Pediatric Surgery resident, Hospital Padre Hurtado \& Clinica Alemana Santiago, Universidad del Desarrollo \\ ${ }^{2}$ Professor in Pediatric Surgery and Urology, Hospital Exequiel Gonzalez Cortes \& Clinica Alemana, Universidad de Chile \\ ${ }^{3}$ Pediatric Surgeon, Hospital Padre Hurtado \& Clinica Alemana \\ ${ }^{4}$ Associate Professor in Pediatric Urology, Hospital Padre Hurtado, Universidad del Desarrollo
}

Corresponding Author: Maria Santos C

Address: Pediatric Surgery resident, Hospital Padre Hurtado \& Clinica Alemana Santiago, Universidad del Desarrollo; Email: mariasantosc@gmail.com

Received date: 20 December 2019; Accepted date: 24 January 2020; Published date: 30 January 2020

Citation: María SC, Pedro-José LE, Marina PS, Carolina AM. Umbilical Cord Hernia Associated with a Patent Urachus: A Case Report. Asp J Pediatrics Child Health. 2020 Jan 30;2(1):13-18.

Copyright (C) 2020 María SC, Pedro-José LE, Marina PS, Carolina AM. This is an open-access article distributed under the Creative Commons Attribution License, which permits unrestricted use, distribution, and reproduction in any medium provided the original work is properly cited.

\section{Abstract}

An umbilical cord hernia (UCH) is a form of abdominal wall defect, affecting 6 out of every 10,ooo newborns. The persistence of urachus is an embryonic remnant that connects the bladder to the abdominal wall at the level of the umbilicus, being yet more uncommon. We reviewed the literature, searching in PubMed, under the terms "Hernia of umbilical cord", "Congenital hernia of cord" and "Persistent Urachus". Only a few similar cases of both pathologies associated described were found. Our main objective is to highlight the distinct clinical features, embryogenesis, prognosis and associated anomalies of two infrequent embryopathies. And to describe a infrequent case of both abnormalities presenting simultaneously.

UCH are often misdiagnosed with other abdominal wall deffects, such as omphalocele, umbilical hernias, gastroschisis and umbilical cord cysts. The normal cord insertion, adequate muscle development of the abdominal wall and a wall defect less than $5 \mathrm{~cm}$ is what differentiates it from an omphalocele. UCH has a low morbidity overall, as it is not associated with other anomalies. The most frequently observed urachal malformations are the persistence of a urachus and urachal cyst. The prenatal diagnosis of patent urachus is made by ultrasound or magnetic resonance, being easily mistaken with abdominal wall defects, confirming the diagnosis with an ultrasound at birth. The persistence of urachus may resolve spontaneously, if not, surgical resolution is recommended. Similar to a $\mathrm{UCH}$, a patent urachus shows little association with other malformations.

It is important to know the clinical presentation and the diagnostic perinatal methods employed for appropriate management and favorable results for both pathologies. This relies on knowing when to suspect possible associated anomalies and when complementary studies might be needed. It is also important to be aware that there is the possibility of a $\mathrm{UCH}$ and a patent urachus existing simultaneously.

\section{Keywords}

Umbilical Cord Hernia; Urachus; Oligohydramnios; Cyst 


\section{Introduction}

An umbilical cord hernia (UCH) is a form of abdominal wall defect, affecting 6 out of every 10,000 newborns [1]. In a UCH the bowel herniates into the base of a normally inserted umbilical cord through a patent umbilical ring. Diagnosis is based on physical examination, making it crucial to differentiate from other similar abdominal wall defects such as omphalocele, gastroschisis, umbilical hernia or umbilical cyst, all of which are different in anatomy, presentation, management and prognosis. Although difficult at times, the key to making an accurate diagnosis is assessing the position of the cord, its contents and the relation of the wall defect to the cord's insertion. The first impression on physical examination is crucial to guide the physician in making an accurate diagnosis and performing further investigations.

Yet more uncommon is the presence of a concomitant patent urachus. Localized in the preperitoneal space, this is an embryonic remnant derived from the involution of the allantois that connects the bladder to the abdominal wall at the level of the umbilicus. The persistence of the urachus is easily misdiagnosed as cord abnormalities and other urachal abnormalities such as urachal cyst, umbilicalurachal sinus and vesico-urachal diverticulum.
Cases of UCH associated with extracelomic colonic atresia, short gut and patent omphalomesenteric duct have been reported in the literature. But only a few similar cases that describe swelling of the umbilical cord or cord cyst associated with a patent urachus have been described.

Our aim is to present the case of a newborn with both $\mathrm{UCH}$ and patent urachus malformations and highlight the distinct clinical features, embryology and associated anomalies thereof. We also discuss the importance of an adequate management plan to avoid further complications.

\section{Case Report}

A full-term male baby was delivered by emergency C-section due to oligohydramnios (amniotic fluid index 2.7), intrauterine growth retardation and was severely small for gestational age $(2.26 \mathrm{okg})$. During routine prenatal care, the ultrasound showed an umbilical cord cyst of 10 to $12 \mathrm{~cm}$ in length. On physical examination at birth, a cyst at the base of the umbilical cord was noted with no other gross congenital anomalies. (Fig-1) Over the following days the umbilical cord remained moist and increased in size.

A postnatal ultrasound was performed, showing extension of the bladder vertex, consistent with a

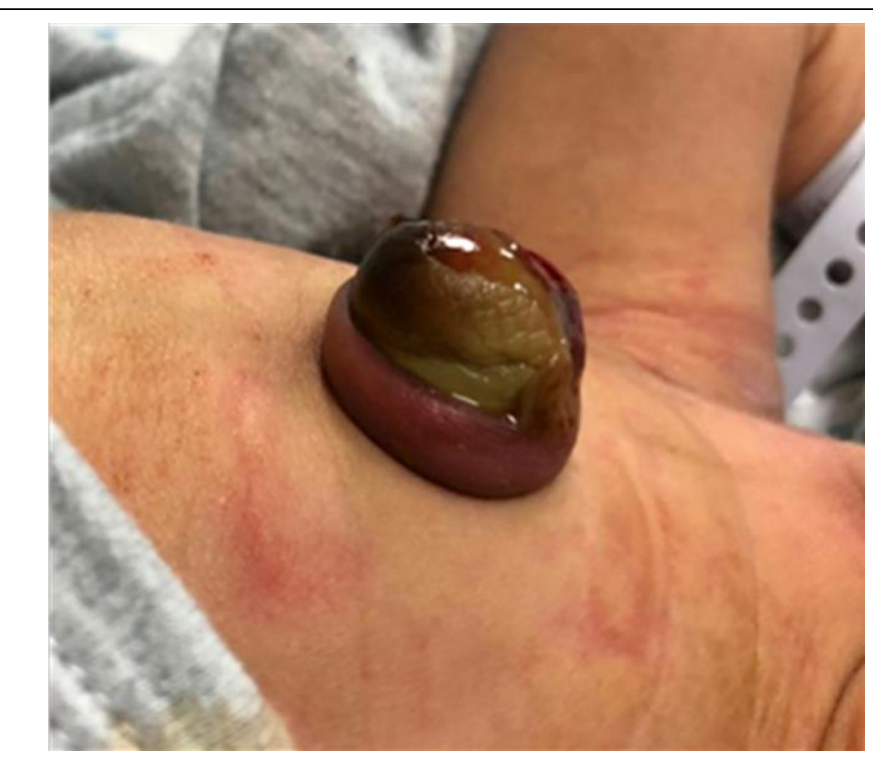

Fig-1:

physical examination at birth, a cyst at the base of the umbilical cord was noted with no other gross congenital anomalies. 
Citation: María SC, Pedro-José LE, Marina PS, Carolina AM. Umbilical Cord Hernia Associated with a Patent Urachus: A Case Report. Asp J Pediatrics Child Health. 2020 Jan 30;2(1):13-18.

\section{Case Report}

persistent urachus, no other anatomic malformations or signs of urinary tract obstruction were observed.

(Fig-2) Surgery was carried out eight days after delivery. A supra- and infra-umbilical midline laparotomy was performed followed by sectioning and ligation of the umbilical vessels. A wide, permeable urachal defect of $2 \mathrm{~cm}$ was identified communicating with the bladder. A Foley catheter was installed filling the bladder with saline solution confirming permeability from the bladder to the umbilical defect. Sectioning of the patent urachus at the base of the bladder dome was performed followed by closure of the bladder with sutures in two planes. To complete the operation, closure of the abdominal wall and an umbilicoplasty was performed. The Foley catheter was left for seven days. There were no intraoperative complications and postoperative recovery was uneventful. The patient was discharged nine days later in a good clinical condition. One month after surgery, the umbilical scar looked acceptable and there was no evidence of recurrence or complications on ultrasound examination.

\section{Discussion}

UCHs arise due to a failure of closure of the abdominal wall. This occurs following return of the

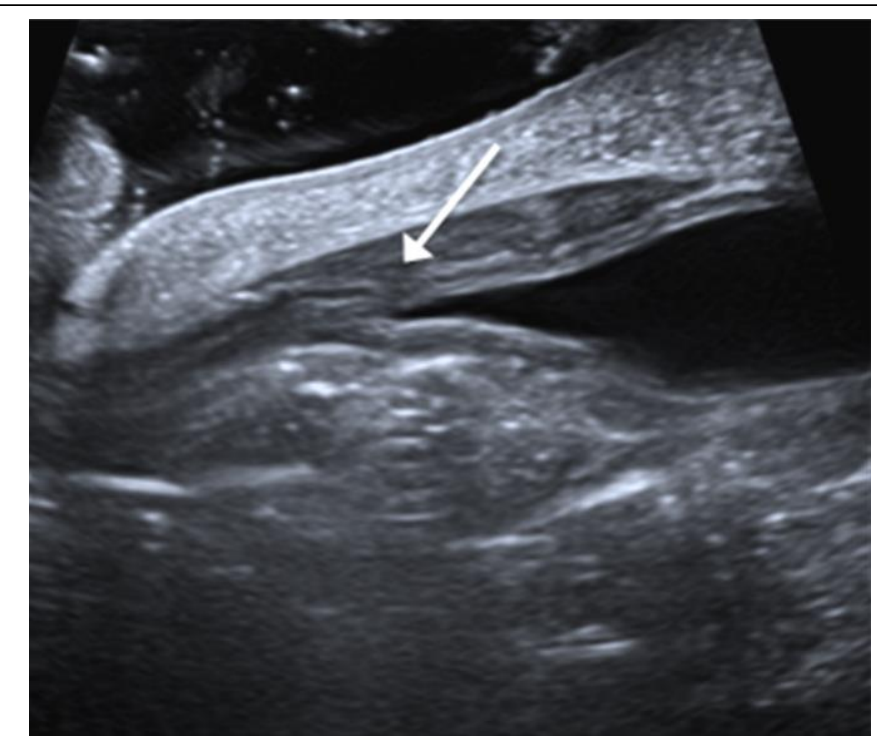

Fig-2:

postnatal ultrasound was performed, showing extension of the bladder vertex, consistent with a persistent urachus.

physiologically eviscerated abdominal contents to the umbilical coelom during the fetal period. It is commonly misdiagnosed as a small omphalocele which differentiates itself by having a normal cord insertion, adequate muscle development of the abdominal wall and a wall defect less than $5 \mathrm{~cm}$. Omphaloceles also present with healthy skin surrounding the base of the cord. We present a table with the main differential diagnoses of $\mathrm{UCH}$ comparing embryological origin, clinical features, associated anomalies and prognosis. (Table-1)

The management of UCH begins at the point of delivery, as inadequate clamping of the umbilical cord may cause damage to its contents. UCH represents a defect at a more advanced stage of embryological development than the other aforementioned abnormalities'. UCH has a lower morbidity overall, as it is not associated with other anomalies, has fewer complications and is relatively straightforward to resolve with an excellent prognosis. Furthermore, the surgical procedure to manage a UCH carries a lower morbidity in comparison to that for gastroschisis and omphalocele.

As mentioned previously, the urachus is an embryologic remnant derived from the lack of obliteration of the allantois lumen. It carries arteries on either side, which undergo fibrosis forming the medial umbilical ligaments. The most frequently observed urachal malformations are the persistence of a urachus and urachal cyst. Due to their anatomical 
Citation: María SC, Pedro-José LE, Marina PS, Carolina AM. Umbilical Cord Hernia Associated with a Patent Urachus: A Case Report. Asp J Pediatrics Child Health. 2020 Jan 30;2(1):13-18.

\begin{tabular}{|c|c|c|c|c|c|c|}
\hline \multicolumn{7}{|c|}{ Table-1: Differential diagnosis of abdominal wall defects. } \\
\hline & \multirow[t]{2}{*}{$\mathrm{UCH}$} & \multicolumn{2}{|c|}{ Cord cyst } & \multirow[t]{2}{*}{ Omphalocele } & \multirow[t]{2}{*}{ Gastroschisis } & \multirow[t]{2}{*}{$\begin{array}{l}\text { Umbilical } \\
\text { hernia }\end{array}$} \\
\hline & & Real cyst & Pseudo cyst & & & \\
\hline Definition & $\begin{array}{l}\text { Herniation } \\
\text { of the } \\
\text { umbilical } \\
\text { cord. }\end{array}$ & $\begin{array}{l}\text { Accumulation } \\
\text { of fluid within } \\
\text { an epithelial } \\
\text { capsule, } \\
\text { derived from } \\
\text { the allantois } \\
\text { or } \\
\text { omphalomese } \\
\text { nteric duct. }\end{array}$ & $\begin{array}{l}\text { Wharton } \\
\text { gelatin } \\
\text { edema and } \\
\text { liquefaction } \\
(8,9) \text {. }\end{array}$ & $\begin{array}{l}\text { Anterior central } \\
\text { defect of the } \\
\text { abdominal wall, } \\
\text { with } \\
\text { evisceration of } \\
\text { intestinal organs } \\
\text { covered by } \\
\text { amniotic sac. }\end{array}$ & $\begin{array}{l}\text { Evisceration of } \\
\text { abdominal organs } \\
\text { through the } \\
\text { abdominal wall, } \\
\text { on the right side } \\
\text { of the umbilical } \\
\text { cord. }\end{array}$ & $\begin{array}{l}\text { Protrusion of } \\
\text { the contents of } \\
\text { the abdominal } \\
\text { cavity through a } \\
\text { weak point of } \\
\text { the umbilical } \\
\text { ring. Defect } \\
\text { covered by skin. }\end{array}$ \\
\hline Embryology & $\begin{array}{l}\text { Persistenc } \\
\text { e of } \\
\text { physiologi } \\
\text { cal } \\
\text { herniation } \\
\text { of thee } \\
\text { midgut } \\
\text { after 10-12 } \\
\text { wks. of } \\
\text { gestation } \\
\text { (3). }\end{array}$ & \multicolumn{2}{|c|}{$\begin{array}{l}\text { Unknown: It is thought to be } \\
\text { an alteration of the } \\
\text { embryogenesis of the vessels } \\
\text { and the physiological } \\
\text { herniation of the small } \\
\text { intestine. }\end{array}$} & $\begin{array}{l}\text { Umbilical defect } \\
\text { due to a failure } \\
\text { in the lateral } \\
\text { folding of the } \\
\text { embryonic disc. }\end{array}$ & $\begin{array}{l}\text { Incomplete fusion } \\
\text { of the lateral folds } \\
\text { during the } 4 \text { th } \\
\text { week of gestation. } \\
\text { It is also thought } \\
\text { to be due to a } \\
\text { disruption of the } \\
\text { right umbilical } \\
\text { vein (3). }\end{array}$ & $\begin{array}{l}\text { Failure of the } \\
\text { rectus } \\
\text { abdominis to } \\
\text { fuse at the } \\
\text { midline after } \\
\text { the return of } \\
\text { the midgut to } \\
\text { the peritoneal } \\
\text { cavity, leaving a } \\
\text { defect in the } \\
\text { linea alba (6). }\end{array}$ \\
\hline $\begin{array}{l}\text { Physical } \\
\text { exam }\end{array}$ & $\begin{array}{l}\text { Umbilical } \\
\text { cord } \\
\text { increased } \\
\text { in size } \\
\text { containing } \\
\text { abdominal } \\
\text { viscera } \\
\text { inside it. } \\
\text { Covered } \\
\text { by intact } \\
\text { skin and } \\
\text { subcutane } \\
\text { ous tissue. } \\
\text { Normal } \\
\text { umbilical } \\
\text { cord } \\
\text { insertion } \\
\text { (3). }\end{array}$ & $\begin{array}{l}\text { Generally of } \\
4-60 \mathrm{~mm} \text {, } \\
\text { located } \\
\text { towards the } \\
\text { anterior } \\
\text { abdominal } \\
\text { wall, } \\
\text { between the } \\
\text { umbilical } \\
\text { vessels. } \\
\text { With liquid } \\
\text { contents. }\end{array}$ & $\begin{array}{l}\text { Smaller, and } \\
\text { can be located } \\
\text { anywhere in } \\
\text { the umbilical } \\
\text { cord (8). }\end{array}$ & $\begin{array}{l}\text { Organs covered } \\
\text { by hernial sac } \\
\text { (transparent or } \\
\text { whitish). } \\
\text { Cord insertion } \\
\text { in the distal } \\
\text { portion of the } \\
\text { defect. } \\
\text { Wall defect of } \\
\text { variable size, } \\
\text { can reach the } \\
\text { total diameter of } \\
\text { the abdomen. } \\
\text { Small abdominal } \\
\text { volume (5). }\end{array}$ & $\begin{array}{l}\text { The defect is about } \\
3-4 \mathrm{~cm} \text { in the } \\
\text { paraumbilical } \\
\text { area, usually to } \\
\text { the right of the } \\
\text { cord. Normal } \\
\text { insertion of the } \\
\text { cord. Intact } \\
\text { viscera float in the } \\
\text { amniotic fluid. } \\
\text { Thin and } \\
\text { edematous } \\
\text { intestinal wall (5). }\end{array}$ & $\begin{array}{l}\text { Umbilical } \\
\text { region } \\
\text { increased in } \\
\text { volume. } \\
\text { Defect covered } \\
\text { by intact skin } \\
\text { and } \\
\text { subcutaneous } \\
\text { tissue. } \\
\text { It becomes } \\
\text { more evident } \\
\text { with the } \\
\text { Valsalva } \\
\text { maneuver (4). }\end{array}$ \\
\hline $\begin{array}{l}\text { Association } \\
\text { with other } \\
\text { pathologies }\end{array}$ & $\begin{array}{l}\text { No } \\
\text { associatio } \\
\mathrm{n} \text { with } \\
\text { chromoso } \\
\text { mal } \\
\text { anomalies } \\
\text { if } \\
\text { presenting } \\
\text { as an } \\
\text { isolated } \\
\text { UCH (3). }\end{array}$ & \multicolumn{2}{|c|}{$\begin{array}{l}\text { Persistent cysts during } 2 \text { nd } \\
\text { and 3rd trimester are } \\
\text { associated with abdominal } \\
\text { wall deformities and urinary } \\
\text { tract deformities including } \\
\text { omphalocele and persistent } \\
\text { urachus. } \\
\text { Chromosomal anomalies, } \\
\text { especially trisomy } 18 \text { (7). }\end{array}$} & $\begin{array}{l}50-70 \% \text { with } \\
\text { other major } \\
\text { anomalies } \\
\text { primarily in } \\
\text { cardiac, CNS, } \\
\text { and urogenital } \\
\text { systems. } 30 \text { - } \\
40 \% \text { associated } \\
\text { with karyotype } \\
\text { abnormalities } \\
(3,4) \text {. }\end{array}$ & $\begin{array}{l}\text { 8-10\% are } \\
\text { associated with } \\
\text { other major } \\
\text { abnormalities. } \\
1-3 \% \text { with cardiac } \\
\text { abnormalities. } \\
\text { No association } \\
\text { with karyotype } \\
\text { abnormalities if } \\
\text { isolated } \\
\text { presentation (3). }\end{array}$ & $\begin{array}{l}\text { Rare. No } \\
\text { association with } \\
\text { karyotype } \\
\text { abnormalities } \\
\text { when isolated } \\
\text { presentation } \\
\text { (3). }\end{array}$ \\
\hline
\end{tabular}


Citation: María SC, Pedro-José LE, Marina PS, Carolina AM. Umbilical Cord Hernia Associated with a Patent Urachus: A Case Report. Asp J Pediatrics Child Health. 2020 Jan 30;2(1):13-18.

Case Report

\begin{tabular}{|l|l|l|l|l|l|}
\hline & $\begin{array}{l}\text { Isolated } \\
\text { UCHs } \\
\text { have } \\
\text { excellent } \\
\text { prognosis } \\
\text { (3). }\end{array}$ & $\begin{array}{l}\text { Isolated defect shows good } \\
\text { prognosis (9). }\end{array}$ & $\begin{array}{l}\text { Depends on the } \\
\text { associated } \\
\text { anomaly and } \\
\text { karyotype. }\end{array}$ & $\begin{array}{l}\text { Good prognosis } \\
\text { intestinal } \\
\text { complications (3). }\end{array}$ & $\begin{array}{l}\text { (3). High } \\
\text { probability of } \\
\text { spontaneous } \\
\text { closure and low } \\
\text { incidence of } \\
\text { complications } \\
\text { (4). }\end{array}$ \\
\hline
\end{tabular}

location they are sometimes misdiagnosed as omphalitis, granulomas secondary to scarring of the umbilicus or infection of the umbilical vessels. The prenatal diagnosis of patent urachus is made by ultrasound or magnetic resonance, showing a cystic mass at the base of the umbilical cord communicating with the bladder, being easily mistaken for an omphalocele or gastroschisis ${ }^{4}$. Suspicion of a patent urachus begins with the physical exam by observing an abnormal umbilicus that is permanently wet. The clinical diagnosis is confirmed with US where a connection between the bladder dome and the umbilicus is visualized. Furthermore, a urethrocystogram can be performed, introducing contrasted liquid through the umbilicus which in $\mathrm{UCH}$ shows a conduit that leads to the bladder [2].

The urachal remnants in patients less than six months old normally resolve spontaneously, being supported with urethral catheterization to facilitate their closure. If it fails to resolve spontaneously, surgical resolution is recommended via laparoscopy or open surgery through an umbilical incision. The primary goal for a satisfactory management is to prevent urinary tract infections and, to a lesser extent, avoid neoplastic urachal changes. The risk of malignancy of the umbilical remnant is rare and uncertain [10]. Some authors suggest that the absence of epithelial elements would make it unlikely to undergo malignant degeneration; therefore waiting for spontaneous resolution is a reasonable alternative [11]. Similar to a UCH, a patent urachus shows little association with other malformations and its early, accurate diagnosis is crucial to avoid further complications.

There are few case reports of umbilical cord cysts described in the literature $[7,11,12,13]$, and as mentioned previously it is one of the main differential diagnosis of $\mathrm{UCH}$ and commonly related with persistent urachus. The case described has evisceration of abdominal contents into the cord, not considered as a cyst, but still a cord anomaly which derives from the same embryologic origin. Therefore, we think it is important to rule out the presence of urinary anomaly when a pathologic swelling of the cord is found.

Due to the low incidence of both UCHs and a patent urachus as well as its broad range of differential diagnoses, it is important to know their clinical presentation and the diagnostic perinatal methods employed for appropriate management and favorable results. This relies on knowing when to suspect possible associated anomalies and when complementary studies might be needed, as in the case of a gastroschisis or omphalocele. Furthermore, it is important to note that trivial umbilical pathologies may be misdiagnosed as UCHs and other abdominal defects indicating surgery. It is also important to be aware that despite being a rare occurrence, there is the rather interesting possibility of a UCH and a patent urachus existing simultaneously.

\section{Conflicts of Interest}

We disclose no conflicts of interest, sources of support, or funding for this article.

\section{References}

[1] Victoria T, Andronikou S, Bowen D, Laje P, Weiss DA, Johnson AM, Peranteau WH, Canning DA, Adzick NS. Fetal anterior abdominal wall defects: prenatal imaging by magnetic resonance imaging. Pediatr Radiol. 2018 Apr;48(4):499-12. [PMID: 29550866]

[2] Arlen AM, Smith EA. Disorders of the bladder and cloacal anomaly. Clin Perinatol. 2014 Sep;41(3):69507. [PMID: 25155736] 
[3] Raju R, Satti M, Lee Q, Vettraino I. Congenital hernia of cord: an often misdiagnosed entity. BMJ Case Rep. 2015 Apr 21;2015. pii: bcr2015209642. [PMID: 25899514]

[4] Pakdaman R, Woodward PJ, Kennedy A. Complex abdominal wall defects: appearances at prenatal imaging. Radiographics. 2015 Mar-Apr;35(2):636-49. [PMID: 25763744]

[5] Ionescu S, Mocanu M, Andrei B, Bunea B, Carstoveanu C, Gurita A, Tabacaru R, Licsandru E, Stanescu D, Selleh M. Differential diagnosis of abdominal wall defects - omphalocele versus gastroschisis. Chirurgia (Bucur). 2014 JanFeb;109(1):7-14. [PMID: 24524464]

[6] Thomson WL, Wood RJ, Millar AJ. A literature review of spontaneous evisceration in paediatric umbilical hernias. Pediatr Surg Int. 2012 May;28(5):467-70. [PMID: 22466720]

[7] Nguyen M, Addicott B, Chu J, Parham D, Kim E. Congenital Cyst of the Umbilical Cord. Fetal Pediatr Pathol. 2016;35(5):344-47. [PMID: 27494161]

[8] Svigos J, Khurana S, Munt C, Sinhal S, Bernardo J. Presentation of an umbilical cord cyst with a surprising jet: a case report of a patent urachus. F10ooRes. 2013 Feb 11;2:38. [PMID: 24358887]

[9] Arango-Pineda J. C, Olivares-Concha D. S, RojasSalazar M. F, Quintero-Mejía J.C, Saldarriaga-Gil W. Pseudoquistes del cordón umbilical: reporte de un caso clínico y revisión de la literatura. Revista Colombiana de Obstetricia y Ginecología. 2013 Sept;64(3):344-49.

[10] Copp HL, Wong IY, Krishnan C, Malhotra S, Kennedy WA. Clinical presentation and urachal remnant pathology: implications for treatment. The Journal of urology. 2009 Oct 1;182(4):1921-24.

[11] Haac B, Garcia A, Moore J. Urachal remnant presenting as a giant, cystic umbilical cord. Pediatr Surg Int. 2017 Mar;33(3):393-95. [PMID: 28044180] [12] Tekesin I, Küper-Steffen R. Prenatal Diagnosis and Clinical Course of a Patent Urachus Associated with an Allantoic Cord Cyst and a Giant Umbilical Cord. Ultrasound Int Open. 2018 Sep;4(3):E104-E105. [PMID: 30255165]

[13] Deshmukh HS, Caty MG, Ryan RM, Lakshminrusimha $S$. Intermittent 'bulge' in the umbilical cord. J Perinatol. 2010 Jul;30(7):500-502. [PMID: 20585322]

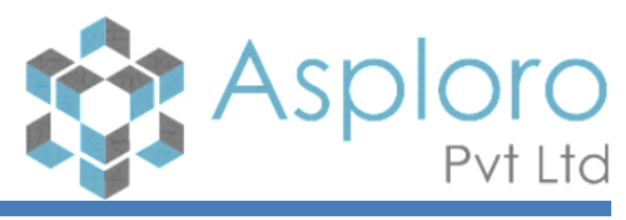

